\title{
ХРОМОСОМНАЯ ИЗМЕНЧИВОСТЬ ТРЕХ ИЗОЛЯТОВ ЭВОРОНСКОЙ ПОЛЕВКИ ALEXANDROMYS EVORONENSIS (RODENTIA, ARVICOLINI)
}

\author{
И.В. Картавцева ${ }^{1}$, И.Н. Шереметьева ${ }^{1}$, Л.В. Фрисман ${ }^{2}$, М.В. Павленко ${ }^{1}$ \\ ${ }^{1}$ ФНЦ Биоразнообразия наземной биоты Восточной Азии ДВО РАН, \\ г. Владивосток \\ ${ }^{2}$ Институт комплексного анализа региональных проблем ДВО РАН, \\ г. Биробиджан
}

Исследованы хромосомные наборы эворонской полевки - эндемика Дальнего Востока России трех изолятов. Предположено наличие двух хромосомных форм / рас. В одной хромосомной расе полевок, обитающих в Эворон-Чукчагирской равнине числа хромосом варьируют от 38 до 40, в другой - в Верхнезейской равнине и Верхнебуреинской впадине варьируют от 36 до 37. Характер хромосомного полиморфизма нуждается в дополнительных исследованиях.

Ключевые слова: кариотип, хромосомные расы, восточноазиатские полевки.

\section{CHROMOSOMAL VARIABILITY OF THE THREE ISOLATES OF THE EVORON VOLES ALEXANDROMYS EVORONENSIS (RODENTIA, ARVICOLINI)}

\author{
I.V. Kartavtseva ${ }^{1}$, I.N. Sheremetyeva ${ }^{1}$, L.V. Frisman ${ }^{2}$, M.V. Pavlenko ${ }^{1}$ \\ ${ }^{1}$ Federal Scientific Center of the East Asia Terrestrial Biodiversity FEB RAS, \\ Vladivostok \\ ${ }^{2}$ Institute for Complex Analysis of Regional Problems FEB RAS, \\ Birobidzhan
}

The chromosomal sets of the Evoron voles, the endemics of the Russian Far East, of three isolates were studied. The presence of two chromosome forms / races is suggested. In one chromosome race of voles inhabiting the Evoron-Chukchagir plain, the number of chromosomes varies from 38 to 40 , in the other - in the Verkhnezeiskaya plain and the Verkhnebureinskaya Depression range from 36 to 37 . The nature of chromosomal polymorphism requires additional studies.

Keywords: karyotype, chromosomal races, East Asian voles.

Эворонская полевка Alexandromys evoronensis (Kowalskaia et Sokolov $1980)$ по данным кариологии $(2 \mathrm{n}=38-40, \mathrm{NFa}=51-54)$ и гибридизации с муйской и полевкой Максимовича (Ковальская, Соколов, 1980; Мейер и др., 1996) была описана как эндемик влажных биотопов Эворон-Чукчагирской равнины нижнего Амура на Дальнем Востоке России (окрестностей оз. Эворон и долины p. Амгунь). Морфологически этот вид близок муйской полевке и полевке Максимовича. Недавно в двух изолированных горных долинах рек Зея 
(северная часть Верхнезейской равнины, р. Арги) и Бурея (Верхнебуреинская впадина, близ г. Чегдомын) были обнаружены серые полевки, по данным митохондриальной ДНК определенны как эворонская полевка (Шереметьева и др., 2016, 2017). Полевки Верхнезейской равнины в кариотипе имели 36 хромосом, в Верхнебуреинской впадины 36-37. Кариотипы полевок с $2 \mathrm{n}=36$ из обеих популяций имели одинаковую изменчивость морфологии одной пары средних размеров, которая могла быть как метацентрической $(\mathrm{M})$, так и акроцентрической (А). Полевка с $2 n=37$ отличалась от полевок с $2 n=36$ разрывом одного из гомологов двуплечей пары хромосом. Пока мы не можем судить о хромосомном полиморфизме полевок из двух новых точек, так как для этого нужны дополнительные исследования. Однако уже сейчас можем говорить, что полевки этих популяций отличаются от полевок ЭворонЧукчагирской равнины по числу и морфологии хромосом.

Данные молекулярного анализа позволяют нам предположить, что мы имеем дело с эворонской полевкой, обитающей в трех изолированных популяциях и имеющей две хромосомные формы / расы. По-видимому, полевки Верхнезейской равнины и Верхнебуреинской впадины принадлежат одной хромосомной расе, и до недавнего времени представляли единую популяцию т.к. имеют сходные кариотипы, в то время как полевки Эворон-Чукчагирской равнины имеют различные хромосомные характеристики и множественный хромосомный полиморфизм (Мейер и др., 1996).

Сравнение кариотипов полёвок из трех изолированных популяций может показать, какие именно перестройки вовлекались в изменчивость кариотипа, а результаты экспериментальной гибридизации полевок разных хромосомных форм / рас могут свидетельствовать о степени их репродуктивной изоляции.

Список литературы:

Ковальская Ю.М., Соколов В.Е. Новый вид полёвки (Rodentia, Cricetidae, Microtinae) из Нижнего Приамурья // Зоологический журнал. 1980. Т. 59. Вып. 9. С. 1409-1416.

Мейер М.Н., Голенищев Ф.Н., Раджабли С.И., Саблина О.Л. Серые полевки фауны России и сопредельных территорий. СПб.: Зоологический институт РАН, 1996. 320 с.

Шереметьева И.Н., Картавцева И.В., Васильева Т.В., Фрисман Л.В. Серые полевки рода Alexandromys из Верхнебуреинской впадины // Зоологический журнал. 2016. Т. 95, № 5. С. 597-603.

Шереметьева И.Н., Картавцева И.В., Васильева Т.В. Обитает ли Эворонская полевка (Alexandromys evoronensis) на Северо-Востоке Верхнезейской равнины? // Зоологический журнал. 2017. № 2. С. 477-484. 